\title{
Jurnal Biolokus
}

Jurnal Penelitian Pendidikan Biologi dan Biologi

Program Studi Tadris Biologi - Fakultas Ilmu Tarbiyah dan Keguruan UIN Sumatera Utara

\section{PENGARUH LINGKUNGAN TEMPAT TINGGAL TERHADAP PENGETAHUAN SISWA TENTANG EKOSISTEM HUTAN MANGROVE DI KABUPATEN DELISERDANG}

\author{
MUHAMMAD IQBAL H. TAMBUNAN \\ Email :iqbaltambunan@yahoo.co.id
}

\begin{abstract}
Penelitian ini bertujuan untuk mengetahui pengaruh lingkungan tempat tinggal terhadap pengetahuan siswa tentang ekosistem hutan mangrove di Kabupaten Deliserdang. Sampel penelitian yaitu siswa kelas VIII SMP Negeri Tahun Pembelajaran 2014/2015 sebanyak 110 siswa dari sekolah yang dekat dan 129 siswa dari sekolah yang jauh dari ekosistem mangrove. Teknik pengambilan data menggunakan tes pilihan berganda berjumlah 20 soal. Analisis data menggunakan uji t. Hasil penelitian ini diperoleh bahwa lokasi tempat tinggal siswa berpengaruh secara signifikan terhadap tingkat pengetahuan siswa terhadap ekosistem mangrove nilai $t=2,216$ dan probabilitas $P=0,028$.
\end{abstract}

Kata Kunci :Pengetahuan, Tempat tinggal, Ekosistem Mangrove

\section{PENDAHULUAN}

Menurut FAO (2007) Indonesia memiliki kawasan mangrove yang terluas di dunia sekitar $19 \%$ dari total hutan mangrove dunia, dan terluas seAsia Tenggara sekitar $49 \%$ dari luas totalnya. Menurut Bakosurtanal (2009) luas hutan mangrove di Indonesia sebesar 3.244.018 Ha. Vegetasi mangrove di Indonesia memiliki 45 spesies (tidak termasuk spesies yang dikenali) dari 75 spesies mangrove sejati yang tersebar di dunia, hal ini berarti Indonesia merupakan negara dengan mangrove terluas dan tingkat keanekaragaman hayati tertinggi. Kawasan mangrove tersebut tersebar disepanjang pesisir Sumatera, Kalimantan, Jawa, Sulawesi, Bali, hingga Papua (Ilman dkk, 2011).

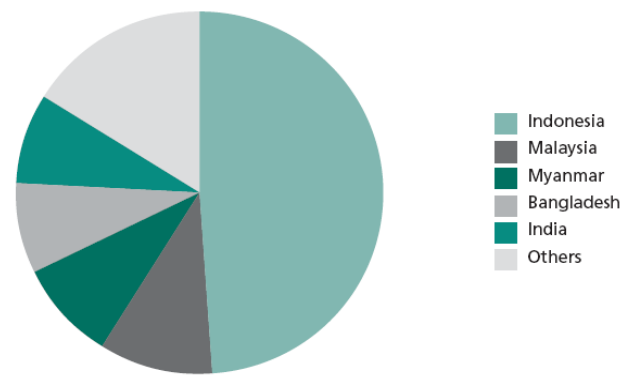

Gambar 1. Negara-Negara di Kawasan Asia yang memiliki area mangrove terluas. (Sumber : FOA, 2007).

Menurut Anwar dan Gunawan dalam Ilman (2011) laju kerusakan mangrove di Indonesia telah mengkhawatirkan, mencapai $530.000 \mathrm{Ha}$ pertahun, ini lebih cepat dari laju rehabilitasi mangrove yaitu sekitar $1.973 \mathrm{Ha}$ pertahun. Tingkat hilangnya hutan mangrove Indonesia dari tahun 1986 hingga tahun 1990 sangat beragam antara satu pulau dengan pulau lainnya. Pulau Papua tingkat kerusakannya yang paling 


\section{Jurnal Biolokus}

Jurnal Penelitian Pendidikan Biologi dan Biologi

Program Studi Tadris Biologi - Fakultas Ilmu Tarbiyah dan Keguruan UIN Sumatera Utara

rendah (8\%), Nusa Tenggara (34\%), disusul Sumatera (43\%), Kalimantan (64\%), Sulawesi (69\%), dan hampir 90\% di Jawa dan Bali (Noor dkk, 2006). Secara keseluruhan, dalam rentang waktu lima tahun tersebut Indonesia telah kehilangan sekitar 2,49 juta Ha hutan mangrovenya.

Pesisir pantai timur Sumatera Utara luas mangrovenya pada tahun 2006 hanya tersisa $41.700 \mathrm{Ha}$ dari luas awal pada tahun 1977 sebesar $103.415 \mathrm{Ha}$, hal ini berarti telah hilang sebesar 59,68\% selama 29 tahun (Onrizal, 2008). Kerusakan ini berdampak pada penurunan volume dan keragaman jenis ikan yang ditangkap, dimana $65,7 \%$ jenis ikan menjadi langka dan $27,5 \%$ jenis ikan tidak pernah lagi tertangkap. Hal ini juga berdampak pada penurunan pendapatan nelayan sebesar 40,5\% (Onrizal et al. 2009). Menurut Hidayati, Kepala Badan Lingkungan Hidup (BLH) Sumut menyebutkan bahwa 90\% hutan mangrove di provinsi Sumatera Utara mengalami kerusakan cukup parah. Penyebabnya antara lain, alih fungsi hutan mangrove menjadi perkebunan sawit, tambak ikan, udang dan lain-lain yang merusak lebih dari 22 ribu hektar.

Dalam Buku Putih Sanitasi Kabupaten Deliserdang (2010), secara geografis Kabupaten Deliserdang memiliki luas wilayah 249,772 $\mathrm{Ha}$ dengan 26,36\% (65.690 Ha) wilayahnya adalah dataran pantai yang meliputi 4 kecamatan yaitu Kecamatan Hamparan Perak, Kecamatan Labuhan Deli, Kecamatan Percut Sei
Tuan dan Kecamatan Pantai Labu. Secara umum vegetasi pohon yang ada merupakan sisa hutan mangrove yang telah dikonversi menjadi tambak sejak tahun 1980.

Bertambahnya kebutuhan akan manfaat kayu bakau memicu terjadinya ilegal dan eksploitasi yang tidak terkendali lagi. Pemanfaatan lahan yang tidak teratur dan tidak memperhatikan aspek ekologis hutan mangrove seperti pembuatan tambak yang sembarangan tanpa disertai pengetahuan masyarakat sekitar mengakibatkan ketidakseimbangan ekosistem hutan mangrove dan akhirnya saat ini menyebabkan kerusakan lahan yang dirasakan langsung oleh masyarakat. Setidaknya ada 5000 hektar hutan mangrove di Paluh Puro Deliserdang telah dijadikan kebun kelapa sawit. Penggarapan hutan mangrove dilakukan hingga mencapai bibir pantai, jika ada pasang besar hutan yang tersisa tak mampu lagi menahan air, hinggga akan melimpah dan mengakibatkan banjir rob.

Untuk mencegah bertambahnya kerusakan hutan mangrove telah dilakukan usaha pencegahan berupa penanaman mangrove kembali dan sosialisasi oleh pemerintah dibawah Dinas Kehutanan, Badan Lingkungan Hidup dan Balai Pengelolaan Hutan Mangrove II Medan, Instansi-instansi, LSM Lingkungan dan Perguruan Tinggi bekerja sama dengan masyarakat. Upaya ini sebagai respon terhadap terjadinya 


\section{Jurnal Biolokus}

Jurnal Penelitian Pendidikan Biologi dan Biologi

Program Studi Tadris Biologi - Fakultas Ilmu Tarbiyah dan Keguruan UIN Sumatera Utara

kerusakan ekosistem mangrove yang berdampak langsung terhadap kehidupan masyarakat pesisir. Namun partisipasi masyarakat terhadap usaha tersebut masih kecil, hanya diikuti oleh sekelompok masyarakat sekitar, ditambah lagi tidak banyak masyarakat yang berkomitmen dalam melaksanakannya, hal ini ditandai dengan tetap berlangsungnya kegiatan penanaman namun setelah itu ditinggalkan tidak diiringi dengan kepedulian untuk menjaga dan merawat.

$\begin{array}{ccr}\text { Masyarakat } & \text { sudah } & \text { memiliki } \\ \text { pengetahuan } & \text { mendasar } & \text { tentang }\end{array}$
mangrove, tetapi belum membentuk persepsi yang baik terhadap ekosistem, sehingga belum membentuk sikap kepedulian terhadap mangrove. Diperlukan berbagai upaya untuk menjaga kelestarian mangrove, salah satunya dengan melibatkan semua kalangan terutama yang berada di lingkungan mangrove serta dengan menumbuhkan kesadaran masyarakat khususnya siswa-siswi sejak dini melalui pendidikan di sekolah dengan penerapan di lingkungan tempat tinggal dan aktivitasnya.

Keberadaan siswa-siswi yang berinteraksi dengan lingkungan mangrove setiap harinya tanpa mengetahui apa sebenarnya fungsi, potensi serta dampak negatifnya perlu dilibatkan untuk membentuk sikap positif terhadap mangrove. Minimnya pendekatan lingkungan secara langsung tentang mangrove di sekolah, cukup memberikan konstribusi bagi rendahnya pengetahuan siswa tentang ekosistem mangrove yang berakibat terhadap proses penafsiran dari stimulasi yang muncul dari pengetahuan, keinginan dan pengalaman tentang ekosistem mangrove. Adanya interkasi siswa terhadap ekosistem mangrove baik yang berada disekitar sekolah dan tempat tinggalnya dapat memengaruhi tingkat pengetahuan terhadap ekosistem mangrove.

Pendidikan dan pengetahuan memiliki hubungan yang erat, adanya pendidikan diharapkan seseorang dengan pendidikan tinggi maka orang tersebut semakin luas pengetahuannya. Namun, perlu ditekankan bahwa seseorang berpendidikan rendah tidak berarti mutlak berpengetahuan rendah pula karena peningkatan pengetahuan tidak mutlak diperoleh dari pendidikan formal akan tetapi dapat diperoleh dari pendidikan nonformal.

Menurut Afriza (2011), pengetahuan siswa tentang hutan bakau di Sekolah Negeri Kabupaten Tanjung Jabung Timur, hanya sekitar $15,2 \%$ sumbangan nilai pengetahuan yang memengaruhi nilai persepsi siswa tentang Hutan Bakau. Sedangkan sisanya, sebesar $84,8 \%$ dipengaruhi oleh faktor lain misalnya pekerjaan orang tua, lingkungan, kedekatan tempat tinggal dengan hutan bakau, frekuensi memasuki kawasan hutan bakau dan lain-lain. Dugaan adanya beberapa hal yang memengaruhi tingkat pengetahuan siswa tentang 


\section{Jurnal Biolokus}

Jurnal Penelitian Pendidikan Biologi dan Biologi

Program Studi Tadris Biologi - Fakultas Ilmu Tarbiyah dan Keguruan UIN Sumatera Utara

ekosistem mangrove yaitu: jarak tempat tinggal siswa dengan ekosistem mangrove. Diduga masih ada faktorfaktor lainnya yang berpengaruh terhadap tingkat pengetahuan siswa tentang ekosistem mangrove.

Dari sekian banyak faktor-faktor yang berpotensi memengaruhi tingkat pengetahuan siswa kelas VIII SMP tentang ekosistem mengrove, maka penelitian ini dibatasi pada lingkungan tempat tinggal siswa dengan mangrove.

\section{TINJAUAN PUSTAKA}

\section{Pengetahuan Siswa Tentang Mangrove}

Pengetahuan merupakan hasil dari tahu dan ini terjadi setelah orang melakukan penginderaan terhadap suatu objek tertentu. Pendidikan menjadikan seseorang yang mendapatkannya mengalami perubahan dari yang tidak tahu menjadi tahu. Pendidikan tentang lingkungan diperlukan untuk merubah pengetahuan seseorang yang mempelajarinya, dari yang tidak tahu menjadi tahu serta memengaruhi dirinya dalam mengambil sikap dan berperilaku. Dengan bertambahnya pengetahuan seseorang tentang lingkungan diharapkan mengubah pandangan dan perilakunya terhadap lingkungan. Sehingga orang yang tadinya tidak perduli dengan lingkungan diharapkan berubah menjadi peduli dengan lingkungannya walaupun upaya tersebut tidak mudah dan membutuhkan dalam waktu relatif lama.
Menurut Notoadmojo (2003), ada beberapa faktor yang memengaruhi pengetahuan seseorang, yaitu: (1) Umur dapat memengaruhi terhadap daya tangkap dan pola pikir seseorang. Semakin bertambahnya usia akan semakinberkembang pula daya tangkap dan pola pikirnya sehingga pengetahuan yang diperoleh akan semakin membaik; (2) Jenis kelamin secara umum prestasi akademik perempuan lebih baik dibandingkan dengan laki-laki. Indikasi temuan ini sebenarnya sudah ada sejak dasawarsa tujuh puluhan. Perempuan ini lebih tekun, lebih teliti (terutama untuk bidang ajar matematika), dan bersedia mendengarkan dengan baik. Sikap emosionalnya yang lebih dominan dibanding pada kemampuan fisiknya telah menempatkan perempuan pada posisi yang sangat baik. (Nuryoto,1998);

Faktor berikutnya yaitu :

Pendidikan dan pengetahuan sangat erat hubungannya, dimana dengan adanya pendidikan diharapkan seseorang dengan pendidikan tinggi maka orang tersebut semakin luas pengetahuannya. Tingkat pendidikan orang tua akan menentukan cara orang tua dalam membimbing dan mengarahkan anaknya dalam hal pendidikan. Mereka akan mengarahkan dan membimbing anaknya untuk terus menambah ilmu sehingga anak tersebut mempunyai minat dalam belajar;(4) Pekerjaan merupakan kegiatan seseorang untuk memperoleh penghasilan guna memenuhi kebutuhan hidupnya sehari- 


\section{Jurnal Biolokus}

Jurnal Penelitian Pendidikan Biologi dan Biologi

Program Studi Tadris Biologi - Fakultas Ilmu Tarbiyah dan Keguruan UIN Sumatera Utara

hari. Jika ditinjau dari jenis pekerjaan yang sering berinteraksi dengan orang lain, lebih banyak pengetahuannya bila dibandingkan dengan tanpa ada interaksi dengan orang lain; (5) Sumber informasi adalah data yang diproses kedalam suatu bentuk yang mempunyai arti sebagai si penerima dan mempunyai nilai nyata dan terasa bagi keputusan saat itu dan keputusan mendatang. Kemajuan teknologi yang begitu pesat menyediakan bermacam-macam media massa yang dapat memengaruhi pengetahuan masyarakat tentang inovasi terbaru.

\section{Ekosistem Mangrove}

Mangrove adalah sekumpulan tumbuh-tumbuhan Dicotyledoneae dan Monocotyledoneae yang terdiri atas jenis tumbuhan yang mempunyai hubungan taksonomi sampai dengan taksa kelas (unrelated families) tetapi mempunyai persamaan adaptasi morfologi dan fisiologi terhadap habitat yang dipengaruhi oleh pasang surut (Menteri Negara Lingkungan Hidup, 2004). Sementara itu, menurut Mastaller dalam Noor (1999) kata mangrove berasal dari bahasa Melayu kuno mangi-mangi yang digunakan untuk menerangkan marga Avicennia dan masih digunakan sampai saat ini di Indonesia bagian timur.

Tumbuhan mangrove memiliki karakteristik morfologi dan fisiologi yang unik. Sistem perakarannya berkembang secara khusus yang dikenal sebagai akar udara (aerial roots), yang sesuai dengan kondisi habitat yang anaerob (tak ada udara) ketika digenangi air. Akar udara berfungsi untuk pertukaran gas dan menyimpan udara selama akar terendam, dapat berupa akar tunjang, akar nafas, akar lutut dan akar papan. Semua spesies mangrove menghasilkan buah yang biasanya disebarkan oleh air. Tipe buahnya bermacam-macam, misalnya buah Rhizoporaceae termasuk buah vivipari, dimana biji telah berkecambah sejak biji masih berada dalam buah dan hipokotilnya telah mencuat ke luar ketika buah masih bergelantungan di pohon induk. (Kitamura,1997).

Ekosistem mangrove memenuhi sejumlah fungsi penting dan memberikan berbagai manfaat baik ditingkat lokal dan nasional. Nelayan, petani dan penduduk pedesaan lainnya bergantung pada ekosistem mangrove berupa hasil kayu (misalnya kayu, tiang, posting, kayu bakar, arang) dan hasil hutannon-kayu (makanan, terutama dari nipah - pakan ternak, gula, obat-obatan dan madu) (FAO, 2007).

Menurut Davies dan Claridge (dalam Noor, 1999), peranan mangrove dalam menunjang kegiatan perikanan pantai dapat dibagi dalam dua hal: (1) Mangrove berperan penting dalam siklus hidup berbagai jenis ikan, udang dan moluska, karena lingkungan mangrove menyediakan perlindungan dan makanan berupa bahan-bahan organik yang masuk kedalam rantai makanan; (2)Mangrove merupakan pemasok bahan organik sehingga dapat menyediakan 


\section{Jurnal Biolokus}

Jurnal Penelitian Pendidikan Biologi dan Biologi

Program Studi Tadris Biologi - Fakultas Ilmu Tarbiyah dan Keguruan UIN Sumatera Utara

makanan untuk organisme yang hidup pada perairan sekitarnya. Produksi serasah mangrove berperan penting dalam kesuburan perairan pesisir dan hutan mangrove dianggap yang paling produktif diantara ekosistem pesisir.

Detritus daun mangrove ternyata mengambil bagian utama dalam memberikan masukan energi pada perikanan (Odum,1994). Vegetasi Mangrove juga dapat memperluas area suatu pulau, menurut Feller dan Sitnik (1996), perkembangan luasan pada mangrove telah terjadi dibeberapa muara sungai besar yang mengalir diatas titik curam di dasar air yang dangkal, seperti Sungai Gangga di Bangladesh, Sungai Fly (aliran sungai panjang) di Papua Nugini.

Diketahui tegakan mangrove dapat melindungi pemukiman, bangunan dan pertanian dari angin kencang atau intrusi air laut. Mangrove juga terbukti memainkan peran penting dalam melindungi pesisir dari gempuran badai. Dusun Tongke-tongke dan Pangasa, Sinjai, Sulawesi Selatan yang memiliki barisan mangrove yang tebal di pantai terlindung dari gelombang pasang (Tsunami) di pulau Flores pada akhir tahun 1993. Sedangkan beberapa dusun yang berbatasan dengan kedua dusun ini yang tidak mempunyai mangrove yang cukup tebal mengalami kerusakan yang cukup parah (Noor, 1999).

Pada hutan mangrove yang dikategorikan sebagai ekosistem lahan basah, penyimpanan karbon mencapai 800-1.200 ton/Ha. Pelepasan emisi ke udara pada hutan mangrove lebih kecil daripada hutan di daratan, hal ini karena pembusukan serasah tanaman aquatik tidak melepaskan karbon ke udara. Adapun tanaman hutan tropis yang mati melepaskan sekitar 50\% karbonnya ke udara. Dengan kemampuan mangrove dalam menyimpan karbon, maka peningkatan emisi karbon di alam tentu dapat dikurangi, sehingga dapat menurunkan pemanasan global, mencegah perubahan iklim global dan menguntungkan dalam perdagangan karbon (Purnobasuki, 2012).

\section{Kabupaten Deliserdang}

Kabupaten Deliserdang terletak diantara $2^{\circ} 57^{\prime \prime}$ - $3^{\circ} 16^{\prime \prime}$ Lintang Utara serta pada $98^{\circ} 33$ - $99^{\circ} 27^{\circ}$ Bujur Timur merupakan bagian dari wilayah pada posisi silang di kawasan Palung Pasifik Barat dengan luas wilayah $2.497,72 \mathrm{Km}^{2}$ $(249,772 \mathrm{Ha})$ atau merupakan $3,34 \%$ dari luas Propinsi Sumatera Utara. Secara administratif terdiri dari 22 Kecamatan dan 394 Desa/Kelurahan (380 desa dan 14 kelurahan).

Kabupaten Deliserdang secara geografis terletak pada wilayah Pengembangan Pantai Timur Sumatera Utara, pada:

a. Dataran Pantai dengan luas $65.690 \mathrm{Ha}$ (26,36\% dari luas Kab. Deliserdang).

b. Dataran Rendah dengan luas 71.934 $\mathrm{Ha} \quad(28,80 \%$ dari luas Kab. Deliserdang). 


\section{Jurnal Biolokus}

Jurnal Penelitian Pendidikan Biologi dan Biologi

Program Studi Tadris Biologi - Fakultas Ilmu Tarbiyah dan Keguruan UIN Sumatera Utara

c. Dataran Tinggi, dengan luas 112.147

$\mathrm{Ha} \quad(44,90 \%$ dari luas Kab.

Deliserdang).

Vegetasi hutan mangrove yang terdapat di pesisir kabupaten Deliserdang didominasi oleh jenis Avicennia dan Rhizoporace secara umum yang merupakan sisa hutan mangrove yang telah dikonversi menjadi tambak sejak tahun 1980-an. (Tambunan, 2010).

\section{METODE PENELITIAN}

Penelitian dilaksanakan pada bulan Desember 2014 - Februari 2015. Lokasi penelitian berada di Sekolah Negeri pada kecamatan sekitar mangrove dan yang jauh dari mangrove di Kabupaten Deliserdang.

Populasi penelitian adalah seluruh siswa kelas VIII di 28 SMP Negeri di Kabupaten Deliserdang yang tersebar di 4 kecamatan yang berbatasan dengan pesisir meliputi Kecamatan Hamparan Perak, Kecamatan Labuhan Deli, Kecamatan Pantai Labu dan Kecamatan Percut Sei Tuan, serta 4 kecamatan yang jauh dari ekosistem laut meliputi Kecamatan Tanjung Morawa Kecamatan Lubuk Pakam, Kecamatan Deli Tua dan Kecamatan Patumbak.

Sampel penelitian diambil secara purposivecluster sampling. Purposive dalam hal ini berdasarkan wilayah sekolah yang berada dekat dan jauh dari ekosistem mangrove. Cluster dalam hal ini mengacu pada kelompok sekolah (tiap kecamatan diambil 1 sekolah) dan pemilihan acak 1 kelas dari beberapa kelas VIII yang ada di masing-masing sekolah yang berbeda lokasinya.

Pada lokasi sekolah yang berada dekat ekosistem mangrove (SMPN 2 Hamparan Perak, SMPN 2 Labuhan Deli, SMPN 4 Pantai Labu Satu Atap dan SMPN 7 Percut Seituan) berjumlah 110 siswa sebagai sampel, sedangkan lokasi sekolah yang berada jauh dari ekosistem mangrove (SMPN 2 Deli Tua, SMPN 1 Lubuk Pakam, SMPN 1 Tanjung Morawa dan SMPN 1 Patumbak) berjumlah 129 siswa sebagai sampel, maka total sampel penelitian yaitu 239 siswa.

Jenis dan Desain Penelitian

Jenis penelitian adalah expost facto, dalam hal ini peneliti melihat adanya hasil yang diperkirakan akibat adanya sesuatu perlakuan yang tidak dipermasalahkan kapan dan oleh siapa terjadinya (Arikunto, 2009).

Dalam penelitian ini faktor lingkungan tempat tinggal siswa dikelompokkan menjadi tempat tinggal siswa yang berada disekitar ekosistem mangrove yang berjarak kurang dari 4 $\mathrm{km}$ serta yang berada jauh dari ekosistem mangrove yang berjarak lebih dari $4 \mathrm{~km}$.

\section{Teknik Pengumpulan Data}

Tes yang digunakan adalah tes pilihan berganda/ objektif test yang bertujuan mengukur pengetahuan dasar 


\section{Jurnal Biolokus}

Jurnal Penelitian Pendidikan Biologi dan Biologi

Program Studi Tadris Biologi - Fakultas Ilmu Tarbiyah dan Keguruan UIN Sumatera Utara

siswa tentang ekosistem mangrove, yang terdiri dari 20 item soal dengan 4 pilihan jawaban. Setiap jawaban yang benar diberi skor 1 dan yang salah diberi skor 0 , dan dikonversikan kepada nilai dengan skala 0 - 100 sehingga akan diperoleh nilai.

\section{Teknik Analisis Data}

Sebelum data hasil penelitian dianalisis, perlu dilakukan uji persyaratan yang meliputi: uji normalitas (Kolmogorov Smirnovtest) dimaksudkan untuk menentukan normal tidaknya distribusi data penelitian, artinya apakah penyebarannya dalam populasi bersifat normal. Homogenitas data diuji dengan pendekatan Levene's Test. Teknik analisis data menggunakan uji t pada taraf signifikan $\alpha=0,05$ dengan bantuan program SPSS 19 for Windows.

\section{HASIL PENELITIAN}

Deskripsi Pengetahuan Siswa Tentang Ekosistem Mangrove Berdasarkan Lokasi Tempat Tinggal

Tabel 1. Deskripsi Lokasi Tempat Tinggal mangrove $(\mathrm{N}=70)$ diperoleh antara 25 75 ; mean $=57,71$; simpangan baku $=$ 11,85 sedangkan nilai pengetahuan siswa yang bertempat tinggal jauh dari mangrove $(\mathrm{N}=169)$ diperoleh antara 20 . 95; mean $=61,92 ;$ simpangan baku $=$ 13,941. Berdasarkan uji normalitas data pengetahuan siswa berdistribusi normal $(\mathrm{Z}=1,265 ; \mathrm{P}=0,082)$. Varians data lokasi tempat tinggal terhadap pengetahuan ekosistem mangrove siswa adalah homogen $(\mathrm{F}=2,638 ; \mathrm{P}=0,106)$.

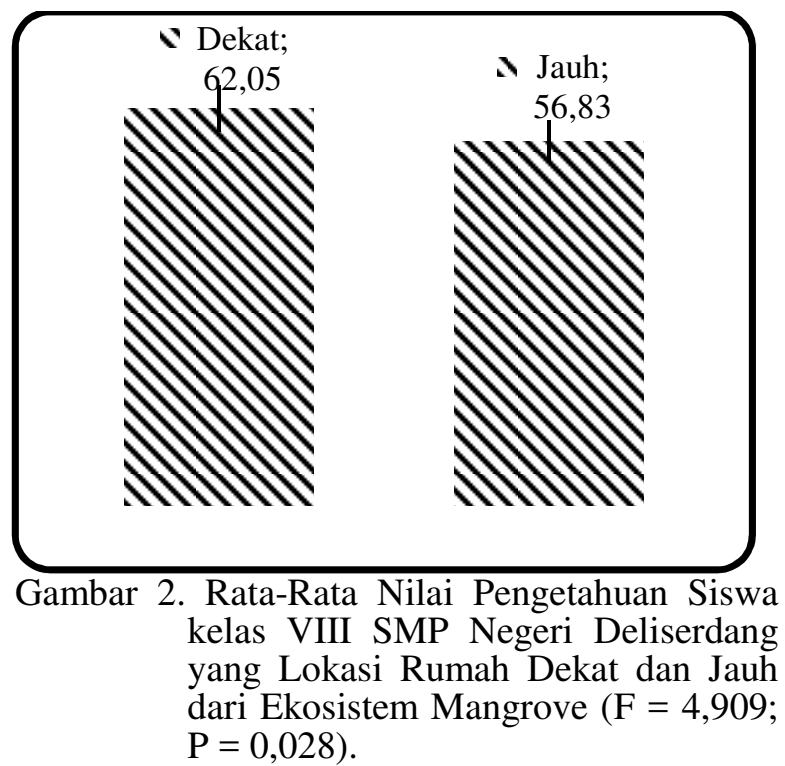

Pengaruh Lokasi Tempat Tinggal Terhadap Tingkat Pengetahuan Ekosistem Mangrove Berdasarkan hasil $U_{j i} t$ diperoleh nilai $\mathrm{t}=2,216$ dan probabilitas $\mathrm{P}=0,028$.

\begin{tabular}{|l|c|c|c|c|c|c|}
\hline $\begin{array}{l}\text { Pengetahuan: } \\
\text { Lokasi Tempat Tinggal } \\
\text { - Mangrove }\end{array}$ & Mean & $\mathrm{N}$ & Std. Dev & $\begin{array}{c}\text { Std. Error of } \\
\text { Mean }\end{array}$ & Min & Max \\
\hline Dekat & 57,71 & 70 & 11,847 & 1,416 & 25 & 75 \\
Jauh & 61,92 & 169 & 13,941 & 1,072 & 20 & 95 \\
Total & 60,69 & 239 & 13,474 &, 872 & 20 & 95 \\
\hline
\end{tabular}

Karena probabilitas $0,028<0,05$ maka

Nilai pengetahuan siswa yang hipotesis nihil (Ho) ditolak, sedangkan bertempat tinggal dekat dengan hipotesis alternatif (Ha) diterima. Hal ini 


\section{Jurnal Biolokus}

Jurnal Penelitian Pendidikan Biologi dan Biologi

Program Studi Tadris Biologi - Fakultas Ilmu Tarbiyah dan Keguruan UIN Sumatera Utara

memperlihatkan bahwa terdapat pengaruh yang signifikan dari lokasi tempat tinggal siswa yang jauh darimangrove dan yang dekat dari mangrove terhadap tingkat pengetahuan siswa tentang ekosistem mangrove di SMP Negeri Deliserdang.

\section{PEMBAHASAN}

\section{Pengaruh Lingkungan Tempat Tinggal Terhadap Tingkat Pengetahuan Ekosistem Mangrove}

Lingkungan tempat tinggal merupakan keadaan, situasi dan kondisi sekitaran tempat dimana masyarakat tersebut hidup, tinggal, mencari nafkah, berkeluarga, belajar dan bersosialisasi.Keadaan lingkungan tempat tinggal sangat penting dalam memengaruhi proses belajar, keadaan lingkungan yang layak untuk siswa belajar dan kesesuaian untuk siswa dalam memperhatikan, mengamati dan menemukan permasalahan dari apa yang dia pelajari disekolah. Karena dengan mempelajari dari apa yang dilihatnya dilingkungan sekitar akan lebih memudahkannya dari pada hanya sekedar pembelajaran teori-teori yang didapatkannya.

Pada hasil penelitian ini menunjukkan bahwa lokasi rumah yang berada dekat dan jauh dari ekosistem mangrove secara signifikan berpengaruh terhadap tingkat pengetahuan siswa.Hal ini dipengaruhi oleh lokasi tempat tinggal yang berada di lingkungan dimana mereka dapat melihat, memperhatikan, mengalami dan berinteraksi dengan ekosistem mangrove dengan baik.

Namun hubungan yang terjadi perbandingan secara terbalik, bahwa nilai rata-rata siswa yang berlokasi jauh lebih tinggi dibandingkan dengan ratarata siswa yang berlokasi dekat. Berbeda dengan penelitian yang dilakukan oleh Harfina (2014) dan Shivakumar (2011) menyimpulkan bahwa wilayah lokasi tempat tinggal berpengaruh secara signifikan terhadap tingkat pengetahuan siswa terhadap ekosistem mangrove dan kepeduliannya terhadap lingkungan.

Beberapa faktor yangdiduga menyebabkan perbedaan tersebut adalah perbedaan tingkat kecerdasan siswa berlokasi jauh lebih baik dari yang dekat. Adanya faktor pendukung sumber informasi yang bisa diakses dengan internet oleh siswa walaupun siswa tersebut jauh dan tidak pernah berinteraksi di lingkungan mangrove. Faktor pembelajaran yang baik terjadi di sekolah sangat berperan besar didalam memotivasi siswa untuk lebih mengetahui lingkungan yang berbeda dengan keadaan sekitarnya.

Ada kecendrungan dari siswa yang berlokasi dekat untuk tidak begitu memperdulikan hal-hal yang ada disekitarnya sehingga perhatian dan keingin tahuan mereka terhadap mangrove tidak terbentuk.Hal yang menyebabkan hal tersebut yaitu lingkungan masyarakat dan keluarga yang belum bisa menanamkan pengetahuan kepada anaknya sehingga anak tidak memiliki rasa ingin tahu dan memicu kurangnya motivasi.

\section{KESIMPULANdan SARAN Simpulan}

Adapun simpulan penelitian tersebut bahwa terdapat pengaruh lokasi tempat tinggal siswa terhadap tingkat pengetahuan ekosistem mangrove pada siswa kelas VIII SMP Negeri di Deliserdang. Walaupun pengaruh tersebut berbanding terbalik. Rata-rata tingkat pengetahuan siswa yang bersekolah dekat lebih rendah dari pada rata-rata siswa yang bersekolah jauh dari ekosistem mangrove.

\section{Saran}

Adapun saran-saran sebagai berikut:

- Bagi para pendidik, diupayakan memberikan materi Pendidikan Lingkungan Hidup (PLH) khususnya tentang ekosistem mangrove menggunakan metode yang bervariasi dan proses belajar mengajar sebaiknya dilakukan dengan pendekatan lingkungan alam sekitar sehingga siswa dapat lebih mengenal lingkungan sekitar. 


\section{Jurnal Biolokus}

Jurnal Penelitian Pendidikan Biologi dan Biologi

Program Studi Tadris Biologi - Fakultas Ilmu Tarbiyah dan Keguruan UIN Sumatera Utara

- Penelitian ini merupakan penelitian awal dalam mencari informasiinfromasi yang dibutuhkan dalam mengetahui pengetahuan siswa terhadap lingkungan sekitarnya. Perlu dilakukan penelitian lanjutan yang lebih spesifik didahului observasi yang lebih baik.

- Penggunaan metode yang berbeda diperlukan untuk mengetahui pengaruh faktor-faktor yang ada secara bersamaan, untuk mendapatkan hasil yang lebih spesifik terhadap faktorfaktor yang memengaruhi pengetahuan siswa terhadap ekosistem mangrove.

\section{DAFTAR PUSTAKA}

Afriza. 2011. Pengetahuan dan Persepsi Siswa Tentang Hutan Bakau di Sekolah Negeri Kabupaten Tanjung Jabung Timur. Skripsi tidak diterbitkan. Jambi: Universitas Jambi.

Arikunto, S. 2009. Manajemen Penelitian. Rineka Cipta: Jakarta.

Azizah, D, N. 2009. Pengaruh Pengetahuan Mangrove dan Pendapatan Terhadap Sikap Masyarakat Petambak Dalam Pelestarian Hutan Mangrove di Kecamatan Brondong Kabupaten Lamongan. Skripsi tidak diterbitkan. Jurusan Geografi. Malang: Universitas Negeri Malang.

Bakosurtanal. 2009. Peta Mangroves Indonesia. Pusat Survey Sumberdaya Alam Laut. Badan
Koordinasi Survey dan Pemetaan Nasional.

FAO. 2007. The World's Mangrove 19802005. FAO Forestry Paper 153. Rome.

Feller., I. C., and Marsha Sitnik. 1996. Mangrove Ecology: A Manual for a Field Course $A$ Field Manual Focused on the Biocomplexity on Mangrove Ecosystems. Smithsonian Institution. Washington DC.

Giesen,Wim; Wulffraat, S; Zieren, M \& Scholten, L. 2006. Mangrove Guidebook For Southeast Asia. FAO and Wetlands International. Thailand.

Harfina. 2014. Faktor - Faktor Yang Memengaruhi Pengetahuan dan Kepedulian Siswa Terhadap Ekosistem Mangrove. Tesis tidak diterbitkan. Program Studi Pendidikan Biologi Pascasarjana Universitas Negeri Medan. Medan.

Ilman, M., Iwan T.C.W., and I N. N. Suryadiputra. 2011. State of the Art Information on Mangrove Ecosystems in Indonesia. Wetlands International _ $\quad$ Indonesia Programme. Bogor.

Kitamura, S., Chairil Anwar., Amalyos Chaniago dan Shigeyuki Baba. 1997. Buku Panduan Lapangan Mangrove di Indonesia. Proyek 


\section{Jurnal Biolokus}

Jurnal Penelitian Pendidikan Biologi dan Biologi

Program Studi Tadris Biologi - Fakultas Ilmu Tarbiyah dan Keguruan UIN Sumatera Utara

Pengembangan Mangrove

Berkelanjutan Dep. Kehutanan

Republik Indonesia dan JICA.

PassKress Communications:

Denpasar, Bali.

Noor, Y. S., M. Khazali, dan I N.N. Suryadiputra. 1999. Panduan Pengenalan Mangrove di Indonesia. PHKA/WI-IP, Bogor.

Notoadmojo, S. 2003. Pendidikan dan Pelaku Kesehatan. Rineka Cipta: Jakarta.

Nuryoto, S. 1998. Perbedaan Prestasi Akademik Antara Laki-laki dan Perempuan Studi di Wilayah Yogyakarta. Jurnal Psikologi, (2):16 -24 .

Odum, E. P. 1994. Dasar-Dasar Ekologi Edisi Ketiga. (Diterjemahkan oleh Tjahjono Samingan dan B. Srigandono). Gadjah Mada University Press: Yogyakarta.

Onrizal \& Kusmana, C. 2008. Studi Ekologi Hutan Mangrove di Pantai Timur Sumatera Utara. Biodiversitas. Vol : 9, (1): 25-29.

Purnobasuki, H. 2012. Pemanfaatan Hutan Mangrove Sebagai Penyimpan Karbon. Dept. Biologi, FST Universitas Airlangga. Buletin PSL Universitas Surabaya. Vol: 28, hal : 3-5.
Shivakumar, G.S and Vamadevappa, H.V. 2011. Environmental Concern among the Secondary School Students. Indian Streams Reserach Journal. Vol.1,Issue.XI/Dec; pp.1-4.

Tambunan, A. 2010. Buku Putih Sanitasi Kabupaten

Deliserdang.

Pemerintah

Kabupaten

Deliserdang: Deliserdang. 